\title{
The impact of capital market imperfections on the relationship between competition and corporate performance
}

\author{
Frederiek Schoubben * \\ Cynthia Van Hulle ${ }^{\S}$
}

\begin{abstract}
This paper explores the relationship between product market competition and firm performance under different levels of information-related capital market imperfections. We show empirically, on a sample of listed as well as unlisted firms, that for companies suffering from financing constraints, increasing competition leads to a decrease in both productivity and profitability while the opposite holds for non (less) constrained firms. This result is robust to alternative measures of competition and can be explained by differences in access to external financing and its impact on investment behavior. Combining the logic of option theory with the literature on competition, we argue that the value of postponing investment is influenced by both the intensity and the type of competitive interaction. Intense and aggressive competition pressures firms to exercise investment options early. For firms with limited access to external financing this pressure to invest exacerbates financing constraints, forcing them to leave valuable investment options unexercised. Overall, our results suggest that competition is not necessarily beneficial for firm performance and that the positive relation that is usually found in the recent governance literature, can be due to restricting the sample to listed firms, i.e., companies that suffer least from capital market imperfections.
\end{abstract}

JEL classification: G3; G31; G32

Keywords: $\quad$ Firm performance; Financing constraints; Product market competition; Stock listing; Productivity; Profitability

* (Corresponding author) Lessius University College, Department of Business Studies, Korte Nieuwstraat 33, 2000 Antwerpen, Belgium; email: frederiek.schoubben@lessius.eu; K.U.Leuven, Faculty of Business and Economics, Department of Accountancy, Finance and Insurance (Research Centre Finance), Naamsestraat 69, 3000 Leuven, Belgium; email: frederiek.schoubben@econ.kuleuven.be

$\S$ K.U.Leuven, Faculty of Business and Economics, Department of Accountancy, Finance and Insurance (Research Centre Finance), Naamsestraat 69, 3000 Leuven, Belgium; tel. + (32) 16 326734; email: cynthia.vanhulle@econ.kuleuven.be 


\section{INTRODUCTION}

It is generally accepted that product market competition affects firm performance. Although

Nickell (1996) indicates that most people believe that competition is a good thing, theory and empirical evidence are not conclusive about its effects. This also holds for the relationship between firm performance and competition. While at a first cut the traditional StructureConduct-Performance paradigm predicts a negative relationship (competition reduces monopoly rents), the empirical evidence is not clear on this score (see Robinson and McDougall, 1998, for a discussion). In fact, although a number of studies show that performance and competition are negatively related (e.g., Hill and Hansen, 1991; Ghosal, 2002; Slade, 2004; Goddard, Tavakoli and Wilson, 2005), a growing body of research linking corporate governance to competition, finds that competition actually improves firm performance (e.g., Nickell, 1996; Nickell, Nicolitsas and Dryden, 1997; Januszewski, Köke and Winter, 2002; Hou and Robinson, 2006). The latter studies, which typically focus on samples of listed firms only, explain the positive relationship shown by the data by arguing that competition improves the firms' strategic and/or investment decisions through better managerial incentives and monitoring quality (e.g., Bozec, 2005; Karuna, 2007). However, this logic implicitly presumes that firms have easy access to the financial resources required for improvement, which need not be the case. It has been well recognized in the theoretical literature that in the presence of financing constraints, firms rather suffer from competition than benefit from it (e.g., Povel and Raith, 2004 or Maurer, 1999, for an overview). However, there is no direct empirical evidence on this issue. ${ }^{1}$ This paper aims at contributing on this latter score. To that end our sample not only includes listed firms but also unlisted ones of comparable size. After all, Claessens and Tzioumis (2006) and Giannetti (2003), among

\footnotetext{
${ }^{1}$ Most empirical research in this area has revolved around analyzing the association between debt and product market strategies (e.g., Chevalier 1995a, 1995b; Phillips, 1995; Kovenock and Phillips, 1997; Zingales, 1998; and Campello, 2003, 2006).
} 
others, point out that in many countries in the world, and in Europe in particular, most of even the larger firms remain unlisted. ${ }^{2}$ As a result, these latter companies are faced with information asymmetries causing them to be more financially constrained compared to listed firms (e.g., Kim, 1999; Maherault, 2000; Holod and Peek, 2007).

This paper adds to the literature in three ways. To our knowledge, this research is the first to offer empirical evidence on how competition affects firm performance differently depending on access to external financing. This adds to our understanding of how financing constraints affect a company's competitive position. Second, our findings provide additional insight into some of the conflicting findings in the literature. They show that results from samples consisting predominantly of listed firms (as is typically the case in the governance literature concerning competition) may be at odds with those generated by samples that mainly include unlisted companies. Third, our paper is the first to document how different aspects of competition (in our case, market concentration and strategic interactions) affect firm performance under different degrees of capital market imperfections and how these aspects interact with each other. ${ }^{3}$

The logic of real options theory offers a direct way to link financing constraints with competitive pressure and performance. Specifically, McDonald and Siegel (1986) and Pindyck (1988), among others, show that in case there is no competition, uncertainty causes firms to postpone investment because of the time value embedded in the investment option. However, in contexts where competitors can pre-empt, firms are pressured to exercise their investment options without delay (e.g., Dixit, 1989; Williams, 1993; Grenadier, 1996, among

\footnotetext{
${ }^{2}$ Claessens and Tzioumis (2006) construct a database of all large firms (operating revenues above $\$ 50$ million) of 19 European countries. They report that about $87 \%$ of these companies are private and only $13 \%$ are listed. As a European stock market typically requires a minimum size of about 1.5 million euros in equity book value, all the firms in the study amply satisfy the minimal size requirement for listing.

${ }^{3}$ Karuna (2007) provides some indirect evidence of the importance of distinguishing different aspects of competition in explaining its relation with agency costs. He concludes that market concentration can not be considered the only measure of product market competition.
} 
others). In fact, Akdogu and Mackay (2006) show empirically that as competitive intensity increases, companies indeed invest more quickly. As a result, firms with limited access to sources of financing can be forced to leave valuable investment opportunities unexercised. By combining this logic of real option theory with the governance perspective, we are able to derive testable hypotheses about the impact of competition on firm performance depending on the capital market imperfections firms are faced with.

We study two measures of competition that capture different aspects of the competitive environment. The first measure represents the intensity of competition in the form of market concentration. While many empirical studies show that this measure of competitive intensity affects firm performance directly (e.g., Nickell et al., 1997; Hou and Robinson, 2005, among others), Ghosal and Loungani (1996, 2000) and Akdogu and Mackay (2006) also report an impact on investment behavior. Furthermore, Fudenberg and Tirole (1984) and Bulow, Geanakoplos and Klemperer (1985) show that apart from market concentration, investment behavior is also affected by the optimal reaction of firms towards expansion of their competitors' market shares. Therefore, we introduce competitive interactions as a second aspect of competition. To that end, we use an empirical version of the competitive strategy measure (CSM), based on the work of Sundaram, John and John (1996). CSM allows to distinguishe between industries operating under more aggressive competition, i.e., competition in strategic complements, and industries operating under more accommodating competitive strategies, i.e., strategic substitutes. Of particular interest here is the fact that when competition is in strategic complements rather than strategic substitutes, profitability improves when a firm increases its investment level in reaction to competitors raising their investment. In turn, real option theory then predicts extra pressure to exercise the investment option early in order to capture those increased profits (i.e., similar to early exercising of a 
call on a dividend-paying stock). Again, firms with limited access to extra financing can be forced to leave this valuable option unexercised.

In constructing a sample of comparable firms that encompasses a wide range of differences in access to external finance, we include - except for some obvious pruning - all large Belgian companies that file consolidated financial statements, i.e., both listed and unlisted firms. Although it reduces sample size, using only Belgian firms with consolidated accounts offers several advantages. First, looking only at one country data provides a clean testing ground for our hypotheses because it avoids the problem of having to control for possibly many institutional differences that can confound results. Furthermore, Belgium is a typical continental European country where the bulk of large consolidated companies remains unlisted and where listed firms are predominantly controlled by large shareholders. ${ }^{4}$ As there is little variation in this mode of control, problems with possibly confounding governance factors are reduced. Next, our data selection assures that over our sample period, the consolidated accounts of listed and large unlisted firms are subject to the same accounting and certification rules. Additionally, as filing consolidated accounts is only necessary for large firms, and the size requirements for consolidation are well above the minimal listing requirements on a European stock exchange, size is no barrier to listing for any of our sample firms. ${ }^{5}$ Finally, as discussed later on, consolidated accounts also help us to overcome distortions due to the presence of some pyramidal ownership, in particular, the fact that subsidiaries of groups have access to internal capital markets.

\footnotetext{
${ }^{4}$ It is generally accepted that, despite of the predominance of large block holders in the ownership structures of Western European companies, small shareholder protection is adequate to keep the expropriation risk at moderate levels (e.g., La Porta et al., 1999).

${ }^{5}$ The comparability of our listed and unlisted firms is also evidenced by the fact that according to the peer groups constructed by the Amadeus data base, there is no systematic difference between the two classes of firms. In particular, the Amadeus data base constructs a peer group for each firm on the basis of trade descriptions. Within our sample, when in the same industry, listed and unlisted firms generally belong to the same peer group.
} 
Our sample covers the period 1992-2005, and similarly to Giannetti (2003) and Holod and Peek (2007), we use stock listing to differentiate in the degree of information-related capital market imperfections. We find that listed and unlisted firms differ significantly in the way product market competition influences their performance. Competitive intensity, as measured inversely by market concentration, has a negative impact on both total factor productivity and return on assets in unlisted companies. By contrast, but in line with the predominant findings of the literature on governance, listed companies benefit from competitive intensity. Introducing the competitive strategy measure (CSM) reinforces these findings. Specifically, under more aggressive competitive interaction (i.e., competition in strategic complements) the performance of unlisted companies declines while it increases for listed firms compared to the situation where competition is in strategic substitutes. Furthermore, our findings indicate that the impact of market concentration and strategic interaction on firm performance reinforce each other. Preceding findings and interpretations are corroborated by robustness tests including alternative measures of competition and by testing actual financing constraints on the basis of investment-cash flow sensitivity. In fact, the pattern of cash flow sensitivity among unlisted firms indicates the existence of financing constraints that are exacerbated when competitive pressure increases. For listed firms on the other hand, the pattern of cash flow sensitivity points towards free cash flow problems that are reduced by competition. Overall, our results show that both measures of competition, market concentration as well as strategic interactions, drive the disciplining effects for listed firms, on the one hand, and exacerbate the harmful financing constraints for unlisted companies, on the other.

The remainder of this paper is organized as follows. In the next section we give an overview of the literature on the relationship between competition and firm performance, and present our hypotheses concerning the impact of capital market imperfections on this 
relationship. After that, we describe the sample selection, the measurement of variables and methodology. The next two sections present and discuss the results and report on the robustness checks. The final section concludes.

\section{THEORY AND HYPOTHESES}

Below, we first summarize the literature concerning the impact of product market competition on firm performance. Next, we evaluate how information-related capital market imperfections affect listed and unlisted firms differently and how the access to external finance can explain this difference. Finally, we hypothesize how the latter influences the competition-performance relationship.

\section{Product market competition}

An important measure of product market competition that is commonly used is product market concentration. It can be interpreted as an inverse measure of competitive intensity in an industry. As mentioned in the introduction, the traditional Structure-Conduct-Performance paradigm predicts a positive relationship between market concentration and performance because limited competition offers the opportunity to extract monopoly rents. However, subsequent empirical research indicates that confounding effects introduce ambiguity (see e.g., Caves, 2007, for an extensive overview). Furthermore, due to growing interest in corporate governance, the link between agency issues and competition has attracted an increasing amount of attention. Ample evidence shows that agency conflicts strongly impact on managerial decision making (see e.g., Januszewski et al., 2002 and Rogers, 2004, for an overview). In this setting, corporate governance studies typically theorize that intense product market competition ensures that efficient production remains a prime managerial aim (e.g., Nalebuff and Stiglitz, 1983; Hart, 1983). Furthermore, competition also improves 
performance because it reduces free cash flow problems (e.g., Nickell, 1996; Nickel et al., 1997; Jagannathan and Srinivasan, 1999; Karuna, 2007). On the one hand, through the presence of more competitors, a reduction in market concentration offers more opportunities for comparison, improving monitoring quality and reducing agency problems between shareholders and managers. On the other hand, low market concentration is likely to offer less insulation from industry shocks. This in turn increases the probability of bankruptcy, providing incentives for managers to try and avoid this outcome through hard work and less free cash flow waste.

Preceding arguments implicitly presume that companies always have the financial resources available to make the adjustments forced onto them by competitive pressure. This need not be the case. In fact, Povel and Raith (2004) show that in an environment where financing constraints are important, competition will amplify these constraints and limit the reaction capacity of companies to competitive threats. Moreover, Boyle and Guthrie (2003), Hennessy and Whited (2005) and Hovakimian and Hovakimian (2007), have shown, theoretically as well as empirically, that constrained firms tend to solve financing issues by postponing investment. Only under limited competitive pressure is this an option, however, as shown by Akdogu and MacKay (2006). Their study concludes that, in line with the logic of real options, firms in monopolistic industries that run a limited risk of pre-emption have a tendency to delay investment. However, as explained in the introduction, when the risk of pre-emption becomes important, firms do no longer have this opportunity. If binding financing constraints make immediate investment impossible, this will result in underinvestment and performance decline.

Next to market concentration, strategic interactions also affect the pressure to invest quickly. For incumbents can either react aggressively by increasing investment (i.e., in the case of competition in strategic complements) or invest sparingly and follow a more 
accommodating strategy (i.e., in the case of competition in strategic substitutes). Fudenberg and Tirole (1984) and Bulow et al. (1985) have demonstrated that the optimal competitive strategy depends upon the slope of a firm's optimal reaction curve to industry shocks. Specifically, when in a particular industry, a firm's marginal profits increase in competitor output around the industry equilibrium (i.e., the slope of the reaction curve is positive), the optimal response is to match competitor's investment behavior and thus compete aggressively. Conversely, if marginal profits decrease (i.e., the slope of the reaction curve is negative), the optimal response of a firm to an increase in output by a rival is to stay put or even decrease its own output. Contrary to the case of competition under strategic substitutes, under competition in strategic complements, the logic of real options theory predicts early exercise of an investment option ceteris paribus. For similar to the case of an early exercise of a call option on a dividend paying stock, the fact that firms forgo profits by not investing immediately causes them to invest more quickly. ${ }^{6}$ Of course, the second situation again presupposes that financing sources are available in order to adapt investment behavior when necessary.

There are many empirical studies on product market competition that use market concentration as a measure of product market competition (see Hou and Robinson, 2006, for an extensive literature review). The alternative measure, based on competitive interactions, has mostly been studied in theoretical models. Sundaram et al. (1996) were the first to construct an empirical competitive strategy measure (CSM) to distinguish between aggressive and more accommodating forms of competitive behavior. They document that this measure explains differences in observed stock market reactions to announcements of R\&D outlays.

\footnotetext{
${ }^{6}$ This could be regarded as the outcome of a sub game perfect equilibrium, whereby, in reaction to competitors raising their investment, a firm immediately exercises its real option to invest. See for example Grenadier, 1996, where, depending upon external circumstances, the model predicts either a sub game perfect equilibrium in which a firm prefers to invest immediately when competitors invest or an equilibrium where a firm prefers to postpone investment at the time the leader decides to invest.
} 
Since then, several papers have used the CSM measure to study the impact of strategic interaction on the announcement effect of new product launches and capital expenditures (Chen, Ik and Lee, 2002 and Chen, Lin and Shih, 2004), the structuring of CEO compensation schemes (Kedia, 2006), the exit by start-up firms (Huyghebaert and Van De Gucht, 2004) and capital structure decisions (Lyandres, 2006).

The preceding discussion implies that competitive interaction affects corporate performance. First, just like market concentration, it is apt to influence the agency costs of free cash flow; competition in strategic complements can be expected to have a strong disciplining effect on discretionary spending because of its pressure on profitability and the need to align investment timing with the investment moves of rivals. Next, the matching behavior in industries where firms tend to compete under strategic complements offers improved opportunities for comparison. In addition, this more aggressive type of competition is also likely to increase the probability of bankruptcy, thereby providing extra incentives for managers to work harder. By contrast, just as in the case of market concentration, the pressure to match the behavior of rivals entails the need to speed up investment and, hence, may exacerbate financing constraints.

\section{Information-related capital market imperfections}

The finance literature provides ample evidence that a strong development of financial systems brings about economic and industry growth (e.g., Levine and Zervos, 1998; Rajan and Zingales, 1998; Demirgüç-Kunt and Maksimovic, 1998). From the perspective of an individual firm, many studies discuss the benefits and costs of going/being public (e.g., Allen, 1993; Pagano, Panetta and Zingales, 1998; Faure-Grimaud and Gromb, 2004). The latter stream of research shows that the most important advantages of listing are transparency/information production in financial markets and subsequent increased access to 
financial resources. This will strongly reduce the information-related capital market imperfections a listed firm is faced with (e.g., Giannetti, 2003 and Holod and Peek, 2007). As for most important disadvantages, research by Jensen (1989), Mayer and Alexander (1991) and Myers (2000), among others, indicates that these are in all likelihood the agency problems between insiders (i.e., management and controlling owners) and outside shareholders.

\section{Hypotheses}

Preceding logic suggests differences in the way competitive pressure influences the performance of listed and unlisted firms. Unlisted companies operate in a less transparent environment and are thus confronted with more information-related capital market imperfections which increase the likelihood of financing constraints. These constraints become harmful when - due to competitive pressure - investment cannot be postponed. Simultaneously, in view of their concentrated ownership and the absence of small public shareholders, unlisted firms are unlikely to benefit from those aspects of competition that involve a reduction of the agency costs of free cash flow and its ensuing increase in efficiency. Therefore, we hypothesize that for unlisted companies, competitive pressure may even result in productivity losses and decreasing profitability. We expect this effect to be most pronounced in industries that are characterized by competition in strategic complements where companies are under extra pressure to invest rapidly.

For listed firms, the situation is very different in the following three aspects. First of all, notwithstanding the transparency/information production in public markets, the presence of small outside shareholders creates conflicts of interest with insiders. ${ }^{7}$ Following Jagannathan

\footnotetext{
7 As in Continental Europe ownership concentration remains substantial in public firms, free cash flow problems likely are smaller as compared to the situation with dispersed ownership. Nevertheless, as compared to unlisted ones, the separation between ownership and control is more important, and conflicts of interest may arise.
} 
and Srinivasan (1999) and Rogers (2004) we argue that the presence of more rivals mitigates such problems because the increased competitive pressure provides more opportunities for comparison. Furthermore, this mechanism is likely to function very effectively when competition is in strategic complements because the matching behavior improves comparability further. Finally, unlike unlisted firms, listed companies have better access to outside financing and therefore have more opportunities to develop an effective response to the strategies of rivals. We expect this financial flexibility to be especially helpful in less concentrated industries competing in strategic complements where the benefits of immediate investment likely outweigh the real option value of waiting (e.g., Akdogu and MacKay, 2006). Preceding logic implies the following two hypotheses:

Hypothesis 1: Higher competitive pressure, as measured by lower market concentration, improves the performance of firms that do not suffer from severe information-related capital market imperfections (i.e., listed companies). For firms that are confronted with severe information-related capital market imperfections (i.e., unlisted firms), this impact is less beneficial or even detrimental.

Hypothesis 2: Higher competitive pressure under the form of aggressive strategic interactions (i.e., competition in strategic complements) improves the performance of firms that do not suffer from severe information-related capital market imperfections (i.e., listed companies). For firms that are confronted with severe information-related capital market imperfections (i.e., unlisted firms), this impact is less beneficial or even detrimental.

\section{SAMPLE, VARIABLES AND METHODOLOGY}

\section{Sample}

Our sample covers the 14 years 1992-2005 and initially consists of all consolidated financial statements of Belgian firms. These data were gathered from the NBB, the National Bank of 
Belgium, and Van Dijk Belfirst. ${ }^{8}$ Issuing consolidated statements only became a requirement in 1992, and then only for firms of sufficient size. ${ }^{9}$ Moreover, the thresholds are significantly above the minimal size requirements for listing on European stock exchanges, so that lack of size does not hamper our unlisted sample firms to go public. ${ }^{10}$ Because of the presence of pyramidal structures, the status of being unlisted requires special attention. Specifically, we exclude unlisted companies that either have a listed parent or a listed subsidiary. We also exclude all companies that are mere production entities of a large international parent. In order to identify these latter companies we used data from either Amadeus or from the firms' websites. ${ }^{11}$ Finally, we exclude all financial firms. As we wish to avoid selection biases, it is important that companies can enter or leave during the sample period. Therefore, we also include firms that change their public/private status. To minimize the influence of outliers in our analysis, we replace extreme observations of all ratio variables with missing values. ${ }^{12}$ Extreme observations include values in the $99^{\text {th }}$ percentile and, for variables with negative values, also those in the $1^{\text {st }}$ percentile.

\footnotetext{
${ }^{8}$ The Amadeus and Belfirst databases are constructed by the same data provider, Bureau Van Dijk. Belfirst is country-specific (i.e., it encompasses only Belgian data) and contains more detailed financial statement information than Amadeus.

${ }^{9}$ Contrary to the US, larger companies in Europe often split off their production entities into subsidiaries with separate legal identity (e.g., see Dewaelheyns and Van Hulle, 2006 and Bianco and Nicodano, 2006, among others). Hence, to obtain a clear picture of these larger companies one needs to use consolidated accounts.

${ }^{10}$ Filing consolidated accounts becomes obligatory when 2 out of the following 3 size thresholds are exceeded: turnover exceeds 50 million euros, total assets exceeds 25 million euros, the company employs more than 500 workers. From the year 2000 on, these criteria where relaxed to 25 million; 12.5 million and 250 respectively. Although the listed companies in our sample are on average older than their unlisted peers, the average age of both our listed and unlisted sample firms, i.e., respectively 51 and 34 years, indicates well established (mature) firms.

${ }^{11}$ Subsidiaries from parents that have to issue consolidated accounts do not need to issue these consolidated statements themselves. Therefore, our sample generally treats business groups as stand-alone entities. In this way, problems and/or noise caused by including both stand-alones and subsidiaries can be avoided (e.g., within business groups subsidiaries have access to internal capital markets, which may impact on financing constraints issues). However, there are a few exceptions. Listed firms always have to publish such accounts and some unlisted companies may consolidate voluntarily. In our sample 66 unlisted firms consolidate voluntarily and 7 listed companies do not satisfy the size requirement for consolidation but are obliged to consolidate because of their listed status. We performed robustness checks by deleting either of these types of firms. Results were not affected.

${ }^{12}$ Using winsorizing instead does not affect our findings.
} 
$* * * * * * * * * * * * * * * * * * * * * * * * * * * * *$

INSERT TABLE 1 ABOUT HERE

$* * * * * * * * * * * * * * * * * * * * * * * * * * * * * *$

Table 1, Panel A represents the sample composition over the different years. Overall, our sample consists of 2518 consolidated firm year observations for which 1812 correspond to unlisted and 706 to listed companies. ${ }^{13}$ Due to the extensive use of lagged variables in our estimation methodology, the first three years of data are lost in the final estimation of investment models as they are used as instruments for the corresponding variables in later years. Panel B of Table 1 gives an overview of the industry distribution. Manufacturing includes the largest number of firms (137), followed by services (124) and distribution (82). This distribution by industry is quite representative of the Belgian economy as a whole.

\section{Performance measures}

Following a growing literature (e.g., Nickell et al., 1997; Palia and Lichtenberg, 1999; Januszewski et al., 2002; Schoar, 2002; Barth, Gulbrandsen and Schone, 2005), we use a firm's total factor productivity (TFP) as a measure of performance. Firm-level TFP is obtained by estimating a log-linear Cobb-Douglas production function for each broad industry classification (as presented in Table 1, Panel B). Since coefficients on capital and labor can vary by industry, this specification allows for different factor intensities in different industries. The production function estimates per industry are pooled across listed and unlisted companies. The TFP measure for each individual company is the estimated residual of regression models of the following form:

$$
\operatorname{LNVA}_{\mathrm{ijt}}=\alpha_{0}+\alpha_{\mathrm{j}} * \operatorname{LNNETAS}_{\mathrm{ijt}}+\beta_{\mathrm{j}} * \mathrm{LNEMPL}_{\mathrm{ijt}}+\mathrm{e}_{\mathrm{ijt}}
$$

\footnotetext{
${ }^{13}$ In order to avoid selection biases we include in our basic analysis also those firms that went public (or private) during the sample period. Excluding them from the sample, however, does not significantly alter our results.
} 
with $\mathrm{LNVA}_{\mathrm{ijt}}$ representing the output of firm $\mathrm{i}$ in industry $\mathrm{j}$ measured as the natural logarithm of value added, ${ }^{14}$ LNEMPL $_{\mathrm{ijt}}$ labor input measured as employment costs, ${ }^{15}$ LNNETAS $_{\mathrm{ijt}}$ capital employed, ${ }^{16}$ measured as the accounting value of net assets during year $\mathrm{t}$, and $\mathrm{e}_{\mathrm{ijt}}$ an i.i.d. error term which represents the firm-specific TFP in a certain year. Like Schoar (2002), we will use these TFP measures as the dependent variable in our performance models. ${ }^{17}$

As an alternative measure of performance, we use return on assets (ROA). Similarly to Thomsen and Pedersen (2000) and Gedajlovic and Shapiro (1998), we define return on assets as net income (EBIT) divided by the book value of total assets. Although both TFP and ROA are measures of firm performance, they tend to capture a somewhat different aspect. While TFP can be interpreted as the productivity of a company relative to its broad industry classification, ROA captures primarily the profitability of a firm's activities. See Palia and Lichtenberg (1999), Schoar (2002) and Barth et al. (2005), for a discussion on the relation between productivity and profitability. Note that we are unable to include Tobin's Q because this measure is not available for unlisted firms. ${ }^{18}$

\section{Measures of product market competition}

Following Hou and Robinson (2006), market concentration was measured by the Herfindahl Hirschman Index (HHI), which is the sum of squared market shares over all companies in an

\footnotetext{
${ }^{14}$ Value added is defined as total sales less material costs. This way, we implicitly allow for material costs as a third input.

${ }^{15}$ Given limited data availability, we proxy the number of employees by the total employment costs of the company. This is unlikely to cause problems because of the very high correlation between total cost of employees and number of employees.

${ }_{16}$ As in the literature on capital budgeting, net working capital is treated as part of invested assets.

17 Unlike the literature on production functions, where the efficiency measure of Cobb-Douglas and its corresponding input factors are the issue of interest, we do not use correction methods for input factors such as for example the Olley-Pakes correction. As we use TFP solely as a relative performance measure; no corrections other than the fixed effect estimation, industry adjusting and lagging of input factors are made. Our approach to measuring TFP is similar to other studies in the ownership performance literature (Palia and Lichtenberg, 1999; Nickell et al., 1997; Januszewski et al., 2002; Schoar, 2002; Barth et al., 2005, among others).

${ }^{18}$ If we use Tobin's Q for the subsample of listed firms, however, and redo the analysis below, results for listed firms remain unaffected.
} 
industry. We define industries on the basis of triple digit European-wide NACE codes. For each (triple digit Nace code) industry, we regard all consolidated European companies in the Amadeus data base as likely competitors of the Belgian consolidated companies in our sample. ${ }^{19}$ Market shares were calculated based on the proportion of a company's turnover in the total turnover for that particular industry. Because of unavailability of sufficient industry data before 1995 , we calculate the HHI measure on a yearly basis as of $1995 .^{20} \mathrm{We}$ also construct a dummy DHHI that takes the value 1 if the average market concentration of a particular industry in a particular year is above the sample median; otherwise it takes the value 0 .

Next, we calculate Sundaram et al.'s (1996) empirical competitive strategy measure (CSM). However, instead of defining it at firm-level with time series data for each firm, we calculate it across all firms of an industry to obtain an industry-wide perspective. This crosssectional approach is similar to the methodologies of Kedia (2006), Lyandres (2006) and Huyghebaert and Van De Gucht (2004). The former authors show that this approach reduces the noise involved in estimating each firm's CSM. As argued by Lyandres (2006), moreover, the empirical CSM construction presumes symmetrical behavior of competing firms, which supports the notion of industry-wide behavior. Specifically, we consider each (triple digit NACE) industry in our sample and identify the competitor firms as all European firms filing consolidated statements in this industry. Then, we calculate the coefficient of correlation between each firm's marginal profits (i.e., the change in profits divided by change in turnover for a certain year) and the change in competitor output, over all firms in a given industry as a proxy for the slope of the average reaction function. This yields an industry-specific CSM

\footnotetext{
${ }^{19}$ Once they operate in the same industry, as mentioned earlier, the fact that the listed and unlisted firms in our sample generally belong to the same peer group (as defined in Amadeus), suggests that listed and unlisted companies also operate in similar markets.

${ }^{20}$ Note that the years before 1995 only serve to calculate lags of our variables, as required by the GMMmethodology.
} 
value for each of our 149 triple digit NACE industries for any given year ${ }^{21}$. This value is positive when competition is in strategic complements and negative when competition is in strategic substitutes. Finally, we define a dummy, DCSM, which takes on the value 1 if the average industry CSM is positive in a particular year (i.e., aggressive interaction or strategic complements), and 0 otherwise (i.e., appeasing interaction or strategic substitutes). Following Kedia (2006), we apply a dummy specification to distinguish between the type of strategic interactions. Kedia (2006) argues that in order to properly estimate the slope of the reaction function, firm-specific price and output data should be used. As this data is unavailable, we are constrained to using sales data to proxy for the firm's decision variables. Kedia (2006) shows that, when calculated in this way, the competitive strategy measure has the same sign as the slope of the real reaction function, although it differs in magnitude. ${ }^{22,23}$

\footnotetext{
${ }^{21}$ Our CSM measure for a particular industry in a certain year can be formally defined as the correlation coefficient of $\Delta \Pi_{\mathrm{i}} / \Delta \mathrm{S}_{\mathrm{i}}$ with $\Delta\left[\left(\Sigma \mathrm{S}_{\mathrm{j}}\right)-\mathrm{S}_{\mathrm{i}}\right]$ : with $\Delta \prod_{i} \quad=$ the change in profits of firm $\mathrm{i}$

$\Delta \mathrm{S}_{\mathrm{i}} \quad=$ the change in turnover of firm $\mathrm{i}$

$\Delta\left[\left(\Sigma \mathrm{S}_{\mathrm{j}}\right)-\mathrm{S}_{\mathrm{i}}\right] \quad=$ the change in sum of turnover of all firm i's competitors; proxied by the sum of turnover of all firms in a particular industry minus $\mathrm{S}_{\mathrm{i}}$.

${ }^{22}$ A remaining potential problem with estimating the sign of the slope of an industry's reaction function (DCSM) is that misclassification between DCSM 0 and 1 could occur due to an industry-wide demand shock. If all firms of a particular industry face increasing sales and profits over the sample period, reaction functions may shift upward. This could lead to an erroneous classification of an industry as competing in strategic complements while in fact the industry is characterized by strategic substitutes. Conversely, an industry-wide downward shift due to a downward shock in demand and profits could result in an erroneous classification as competition in strategic substitutes. The impact of this problem on our findings should be minimal, however for two reasons. First, in line with Kedia (2006), as we use a cross-sectional industry measure of competitive interaction instead of a firm-specific measure, which lowers the chance of misspecification due to demand shocks. Second, if industry-wide shocks were an important driver of our DCSM-variable, we would observe that industries classified as competing in strategic complements show high industry growth and profits, while the reverse would hold true for industries classified as competing in strategic substitutes. When we calculate the mean and median (European) industry sales growth, we find that there is no significant difference between industries with DCSM= 1 and DCSM $=0$. Profit margins in industries classified as DCSM = 1 are always lower than those with DCSM $=0$ and even significantly so in most years of the sample period.

23 Akdogu and MacKay (2006) suggest two strategy-based explanations for the influence of strategic interactions on the value of waiting. First, strategic real-options theory stresses a reactive explanation where the threat of losing opportunities to rivals prompts own firm investment. Second, industrial organization theory stresses a proactive explanation where own-firm investment is used to affect rivals' investment. Although it may not be possible to disentangle them empirically, both explanations point to the importance of strategic interactions. In our own empirical setup however, even the firms in the high market concentration subsample cannot be considered to be dominant players in their corresponding, Europe-wide industries. This favors the reactive explanation over the proactive explanation.
} 


\section{Performance models}

In order to test our hypotheses, we use the following regression model:

$$
\begin{aligned}
\text { Performance }_{\mathrm{it}}= & \alpha_{\mathrm{i}}+\beta_{1} * \mathrm{SIZE}_{\mathrm{it}}+\beta_{2} * \mathrm{FINLEV}_{\mathrm{it}}+\beta_{3} * \mathrm{GROWTH}_{\mathrm{jt}}+ \\
& \delta_{1} * \mathrm{COMPETITION}_{\mathrm{it}}+\delta_{2} * \mathrm{~L}_{\mathrm{it}}+\delta_{3} * \text { Interactions }
\end{aligned}
$$

As discussed earlier, we employ two alternative performance measures. We use TFP as a productivity measure and return on assets (ROA) as a measure of a firm's profitability. The parameter $\alpha_{\mathrm{i}}$ represents an unobservable firm-level fixed effect. Following the literature, we define control variables to take firm characteristics into account and then add the variables of particular interest to our study. Many studies on firm performance have used size, leverage and growth opportunities as control variables. Specifically, firm size serves to control for possible economies of scale. Financial leverage is used to control for the influence of capital structure on investment behavior and managerial discretion. Finally, sales growth is included to capture the impact of demand conditions and business-cycle fluctuations on performance. We measure size (SIZE) as the natural logarithm of total assets; leverage (FINLEV) is measured as interest bearing debt relative to total assets and Growth opportunities (GROWTH) are measured by the relative change in sales (see e.g., Schoar, 2002; Gedajlovic and Shapiro, 1998, among others).

Next, we augment Equation (2) with measures of competition. We use either market concentration (HHI) or the competitive strategy measure (DCSM). We define a listing dummy as $\mathrm{L}_{\mathrm{it}}=1$, if firm $\mathrm{i}$ was listed in year $\mathrm{t} ; \mathrm{L}_{\mathrm{it}}=0$ otherwise. Finally, we also use interaction terms between competition and the listing dummy to test for differences between the listed and unlisted subgroups. The appendix provides an overview of the variables' definitions. 
As Arellano and Bond's (1991) generalized method of moments (GMM) methodology replaces variables by their instruments, we can control for the endogeneity of the public/private status, at least if we do not use split samples but instead keep listed and unlisted companies in the same data set and use interaction terms. ${ }^{24}$ Similarly, the replacement by their respective instruments also controls for the endogeneity in the other explanatory variables. Specifically, the technique consists in taking the first differences of the model and then applying GMM using the lagged levels of the endogenous variables as instrumental variables. By taking first differences, we also control for the unobserved firmlevel fixed effect and possible measurement error. In addition, the use of fixed firm effects has the advantage that it controls for systematic differences in performance across firms.

\section{RESULTS}

\section{Descriptive statistics and univariate analysis}

The descriptive statistics in Table 2, Panel A document differences between listed and unlisted companies for our performance measures and control variables. Listed companies outperform their unlisted peers based on productivity (TFP) as well as profitability (ROA). Next, listed firms are significantly larger, although the difference with unlisted companies is of no great importance economically. The former also hold less financial leverage. Finally, sales growth is significantly higher in listed firms.

$* * * * * * * * * * * * * * * * * * * * * * * * * * * * *$

INSERT TABLE 2 ABOUT HERE

$* * * * * * * * * * * * * * * * * * * * * * * * * * * * * *$

Panels B and C look more closely into the impact of product market competition on both performance measures. Panel B shows that for unlisted firms, the TFP measure is somewhat higher in the most concentrated industries (i.e., DHHI =1). Concerning ROA, the situation is

\footnotetext{
${ }^{24}$ If we repeat our analysis using split samples in stead of interactions, our findings remain intact.
} 
different; firms in the least concentrated subgroup have a higher ROA but the difference, although significant, is not very large economically. For listed companies, the results are more straightforward. Firms under more competitive pressure (i.e. DHHI $=0$ ) perform better in terms of both TFP and ROA. In Panel C, the sample is split up according to the competitive strategy measure (DCSM). Here, none of the differences is significant, although the results support the observation that in terms of productivity and profitability, unlisted firms are negatively affected by aggressive competition (i.e., competition in strategic complements), while listed firms benefit from it.

Finally, Panel D of Table 3 reports the correlations between the performance measures, the measures of product market competition and the control variables. Our measures of firm performance are significantly positively correlated at about 53\%. Also our two measures of competition are correlated but the coefficient is small in absolute value. The negative sign of the correlation suggests, in line with Sundaram et al. (1996), that aggressive competition is more likely when markets are less concentrated. The remainder of Panel D shows low correlations in absolute value among the other independent variables.

Overall, the univariate statistics show that listed firms perform better than their unlisted peers. In line with our hypotheses, the data also suggest that listed companies benefit from competition while the picture for unlisted firms is less clear. However, as confounding factors may influence these results, our findings remain inconclusive.

\section{Multivariate analysis of competitive pressure}

The regression results for the performance models based on Equation (2), are reported in Table 3. The dependent variable in each model is either total factor productivity (TFP) or return on assets (ROA). Models are tested with GMM, following the Arellano and Bond (1991) method. The validity of using lagged values of endogenous regressors as instruments 
was evaluated with the Sargan test of over-identifying restrictions and direct tests of serial correlation in the residuals. The validity of instruments was never rejected. ${ }^{25}$

$* * * * * * * * * * * * * * * * * * * * * * * * * * * * *$

INSERT TABLE 3 ABOUT HERE

$* * * * * * * * * * * * * * * * * * * * * * * * * * * * * *$

In line with earlier empirical studies on firm performance, e.g., Spanos, Zaralis and Lioukas (2004) and Goddard et al. (2005), we find that size has a negative impact on both productivity and profitability, while growth has a positive effect on these performance measures. We also find a negative impact of financial leverage, although most other papers using similar performance models find a positive relationship (e.g., Gedajlovic and Shapiro, 1998; Nickell and Nicolitsas, 1999, among others). This result is largely due to the fact that the main part of our sample consists of unlisted firms. Goddard et al. (2005), for example also find a negative relationship between leverage and profitability on a sample of predominantly unlisted Belgian firms. Finally, consistent with the univariate results, overall, our listed companies also perform better, ceteris paribus, as indicated by the significantly positive stock listing dummy.

More importantly however, Model 1 shows that product market concentration (HHI) has a positive impact on both TFP and ROA. As market concentration can be interpreted as an inverse measure of competitive intensity, the implication is that competition overall has a negative impact on performance. ${ }^{26}$ This is contrary to most empirical studies on product market competition, at least in the governance literature, as these typically report a positive relationship with competition (e.g., Nickell, 1996; Nickell et al., 1997; Januszewski et al., 2002). However, as shown in Table 4, this is due to our sample largely consisting of unlisted

\footnotetext{
25 The M1 and M2 tests, reported in the respective tables, suggest that the error term has a moving average structure of order one, as one would expect in the differenced form of the equation, when the idiosyncratic component of the error term in the level equation is serially uncorrelated. Both tests suggest that variables lagged twice or more are legitimate instruments.

${ }^{26}$ When we replace the continuous variable (HHI) with the dummy variable (DHHI), results remain similar.
} 
firms. Model 2 also includes our measure for competitive strategy (DCSM). As DCSM = 1 indicates competition in strategic complements, the negative sign of its coefficient shows that firms operating in industries characterized by more aggressive interaction have lower productivity (TFP). Again, as we show below, this is driven by the unlisted companies in our sample. Interestingly, also the impact of market concentration remains. This indicates that both measures of competition have a significant impact on performance. ${ }^{27}$

$* * * * * * * * * * * * * * * * * * * * * * * * * * * * *$

INSERT TABLE 4 ABOUT HERE

$* * * * * * * * * * * * * * * * * * * * * * * * * * * * *$

To investigate the difference between listed and unlisted companies, we introduce interactions of the listed dummy with the two measures of product market competition. These results are presented in Table 4. In line with our Hypothesis 1, Model 1 shows a positive effect of market concentration on performance for unlisted firms but a negative effect for listed companies. That is, competitive intensity hurts unlisted companies but improves performance in listed ones. Consistent with our hypothesis 2, the competitive strategy measure shows a similar result; competition in strategic complements reduces performance in unlisted companies while the reverse happens for their listed peers. Overall, these results are consistent with the notion that competitive pressure enhances performance only if firms have sufficient financing resources. ${ }^{28}$ The impact of competition proves to be economically meaningful as well. The inter quartile range for market concentration (HHI) represents a $3.9 \%$ drop in TFP and a $1 \%$ drop in ROA for unlisted companies against an increase in TFP

\footnotetext{
27 Sundaram et al. (1996) argue that the mode of strategic interaction is influenced by the degree of market concentration and therefore estimate an equation explaining their CSM measure as a function of market concentration. In line with this idea we estimate an equation explaining our continuous industry-wide CSM measure by market concentration (HHI). The error term in this auxiliary regression is then used to calculate an instrumented DCSM measure. When we use the latter instead of the original DCSM dummy our findings remain.

${ }^{28}$ In our preliminary analysis we did not include industry effects as they can be considered to be subsumed by the individual firm effects. We checked for the robustness of our results by including industry dummies to capture consistent heterogeneity in performance across different industries. Results were very similar to the ones reported and are available upon request.
} 
and ROA of $10 \%$ and $1.7 \%$ respectively for the listed companies. Similarly, operating in an environment of aggressive competition causes, ceteris paribus, a drop in TFP of $4.8 \%$ and a decrease in ROA of $0.8 \%$ for unlisted companies. For listed firms, on the other hand, aggressive competition boosts productivity by $16 \%$ and profitability by $1.7 \%$, all else being equal.

In Model 2 of Table 4, we use interaction terms for the two measures of competition. To make results more easily interpretable, we apply the dummy variable DHHI instead of the continuous market concentration variable HHI. ${ }^{29}$ The coefficients for the control variables remain largely unaltered between Model 1 and Model 2. In addition, Model 2 indicates that competition in strategic complements $(\mathrm{DCSM}=1)$ only has an effect on unlisted firms when they operate in industries with low concentration; i.e., when $(1-\mathrm{DHHI})=1$. In that case, aggressive competitive interaction harms them, making them about $10 \%$ less productive compared to other firms in their industry and reducing ROA by $1.1 \%$. By contrast, under the same circumstances listed firms benefit. Robustness tests in the section below further support these interpretations. ${ }^{30}$

Before moving on to the section on robustness issues, it is also of interest to note that when we split up the leverage variable by interacting it with the listed dummy, leverage only has a significantly negative impact for unlisted companies; for listed firms the sign reverses. The coefficient is highly significant in case of ROA and marginally significant for the TFP model. This finding is in line with the often used argument that, at least in listed firms, the pressure of debt servicing solves problems of free cash flow, and hence, improves performance (Jensen, 1986; Nickell et al., 1997; Nickell and Nicolitsas, 1999). By contrast, for unlisted firms the results suggest that the pressure of debt servicing creates harmful

\footnotetext{
${ }^{29}$ Similar results obtain if HHI is used instead of DHHI.

${ }^{30}$ Variables L and HHI were deleted when used in the interaction terms of the models of Table 4 to avoid any possible problems of inference. Moreover their interpretation would become difficult.
} 
financing constraints and reduces performance (e.g., Rajan, 1992 and McConnell and Servaes, 1995).

\section{ROBUSTNESS ISSUES}

\section{The Lerner index}

As a first robustness check, we replace market concentration with a Lerner index as an alternative measure for product market competition. Following Aghion et al.'s (2005) methodology, we calculate individual price-cost-margins for companies by dividing the operating profits in a certain year by the sales of that year. Similarly to our HHI measure, we define industries on the basis of triple digit NACE codes and use all European companies from the Amadeus data base that file consolidated accounts. Company-specific price-costmargins are averaged over all companies in a particular industry, resulting in an industryspecific Lerner index (price-cost-margin) for each year (LERN) ${ }^{31}$ Next to the continuous measure of the Lerner index, we construct a dummy (DLERN) that indicates whether the Lerner index of a certain industry is above the total sample's average in a particular year. Aghion et al. (2005) claim that the most important advantage of the Lerner index over market concentration is that it relies less heavily on the precise definition of geographic location and product market environment. Table 5 reports the results for the same performance models as in Table 4 safe for the replacement of HHI with LERN.

$* * * * * * * * * * * * * * * * * * * * * * * * * * * * * *$

INSERT TABLE 5 ABOUT HERE

$* * * * * * * * * * * * * * * * * * * * * * * * * * * * *$

Overall, our results are very robust to this change in measure of product market competition. Price-cost-margins in an industry positively influence productivity of unlisted

\footnotetext{
${ }^{31}$ Note that the continuous Lerner index is significantly positively correlated (about 0.20 ) with our measure of market concentration (HHI).
} 
firms while it has the opposite impact on the listed ones. Since these price-cost-margins (Lerner index) can be interpreted as an inverse measure of product market competition, our conclusions remain that competitive pressure is only beneficial for listed companies. Also the interactions of competitive intensity with competitive interactions remain similar to the models with HHI (Table 4). The interaction of the Lerner index dummy (DLERN) with DCSM reveals that aggressive competition (DCSM $=1)$ is most devastating for unlisted firms in industries with low price-cost-margins. For listed firms on the other hand, aggressive competition is more beneficial in industries with low price-cost-margins.

\section{Cash flow sensitivity of investment}

In a second robustness test, we check the conclusions drawn from the performance models using investment equations. If our arguments and interpretations are correct, we should observe that as competitive pressure mounts, investment decisions by unlisted firms are increasingly hampered by financing constraints, while free cash flow problems in listed firms are reduced. The estimation of investment-cash flow sensitivity models offers opportunities to evaluate the preceding questions (see Fazzari, Hubbard and Petersen, 1988; Kaplan and Zingales, 1997 and Cleary, 1999, for an extensive discussion on investment-cash flow sensitivity). In particular, if investment decisions are purely driven by the net present value rule, internal cash generation should have no impact on investment. However, in practice, either financing constraints or free cash flow problems can cause a positive sensitivity. To distinguish between these two causes, we follow the relevant literature (e.g., Schiantarelli and Sembenelli, 2001; Degryse and de Jong, 2006; Pawlina and Renneboog, 2005) and evaluate the pattern of cash flow sensitivity as a function of the variables of interest in our study, i.e., the listing dummy and the measures of competition. Specifically, if financing constraints are an important driver of our findings concerning the performance for unlisted firms, the latter 
should show a significant cash flow sensitivity that, moreover, increases with competitive pressure. The reason is that if competition enhances financing constraints, cash flow sensitivity should rise as a function of competition. By contrast, the findings reported in the previous section imply that for listed firms the reverse should happen. Specifically, if in listed firms competition improves performance as it limits free cash flow problems, cash flow sensitivity should decrease with competitive pressure.

We use the following standard investment equation, in analogy with Audretsch and Weigand (2005) and Degryse and de Jong (2006), among others, and augment it with the variables of interest for our study:

$$
\begin{aligned}
\frac{\mathrm{I}_{\mathrm{it}}}{\mathrm{K}_{\mathrm{it}-1}}= & \alpha_{\mathrm{i}}+\mu_{\mathrm{t}}+\beta_{1} \frac{\Delta \mathrm{S}_{\mathrm{it}}}{\mathrm{K}_{\mathrm{it}-1}}+\beta_{2} \frac{\mathrm{CF}_{\mathrm{it}}}{\mathrm{K}_{\mathrm{it}-1}}+\beta_{3} \frac{\Delta \mathrm{WC}_{\mathrm{it}}}{\mathrm{K}_{\mathrm{it}-1}}+\beta_{4} \frac{\Delta \text { FINDEBT }_{\mathrm{it}}}{\mathrm{K}_{\mathrm{it}-1}}+\beta_{5} \mathrm{SIZE}_{\mathrm{it}-1} \\
& +\delta_{1} * \text { COMPETITION }_{\mathrm{it}}+\delta_{2} * \text { Interactions }
\end{aligned}
$$

In Equation (3), $\mathrm{I}_{\mathrm{it}}$ stands for gross investment defined as the change in the real capital stock $(\mathrm{K})$ plus depreciation. Capital stock $(\mathrm{K})$ is proxied by tangible fixed assets. The parameter $\alpha_{\mathrm{i}}$ represents an unobservable firm-level fixed effect while $\mu_{\mathrm{t}}$ is used to control for fixed time effects. $\Delta \mathrm{S}$ represents the growth of real sales. As a measure for internally generated funds, we use real cash flow (CF). In line with Bhagat, Moyen and Suh (2005), we take into account that some of the internally generated funds are committed to debtors (via interests) or to the government (through taxes). Therefore, we start out from EBITDA and subtract interests and taxes to arrive at our cash flow measure. All variables are normalized by the capital stock at the beginning of the period. In order to correct for relative price differences over the years, we deflate all nominal values with the consumer price index. Due to the unavailability of a market price for unlisted firms, we use sales growth instead of 
Tobin's Q as a measure for investment opportunities. This approach has also been adopted by other authors like Konings, Rizov and Vandenbussche (2003) and Audretsch and Weigand (2005). However, just as Tobin's Q, this measure may not sufficiently capture investment opportunities. As a result, some of this information can also be reflected in cash flow. In order to identify the liquidity role of cash flow, we augment our investment model with the change in net working capital relative to the real capital stock $(\Delta \mathrm{WC} / \mathrm{K})$, an approach also used by Audretsch and Weigand (2005) and Degryse and De Jong (2006). We further augment our model with standard control variables as typically defined in this literature, i.e., the change in interest bearing debt standardized by the capital stock $(\triangle \mathrm{FINDEBT} / \mathrm{K})$ and SIZE as measured by the logarithm of total assets. Finally, we add the variables of special interest to our study: the measures of competition, the listing dummy and/or interaction terms.

$* * * * * * * * * * * * * * * * * * * * * * * * * * * * *$

INSERT TABLE 6 ABOUT HERE

$* * * * * * * * * * * * * * * * * * * * * * * * * * * * * *$

Model 1 of Table 6 shows that growth opportunities $(\Delta S / K)$ have a positive impact on investment. This suggests that our investment model is not a bad approximation for describing the investment behavior of large Belgian companies. The sign of the change in working capital is negative, indicating that cash flow indeed measures liquidity rather than investment opportunities. In line with other empirical studies, we find that the changes in financial debt and size are positively related to investment (e.g., Degryse and de Jong, 2006 and Audretsch and Weigand, 2005). More interestingly, however, splitting up the cash flow variable according to listing status reveals that there is significant investment-cash flow sensitivity, but only among unlisted firms. This absence of sensitivity in listed companies suggests that, on average, free cash flow problems are limited. In fact, the predominant 
presence of large shareholders in our sample companies likely accounts for this result. ${ }^{32}$ Nevertheless, Models 2 and 3 indicate that one should interpret this finding with care. Model 2 further interacts cash flow sensitivity with the market concentration dummy DHHI while Model 3 uses the strategic interaction dummy DCSM instead. ${ }^{33}$ In Model 2 the term $(1-$ $\mathrm{L})^{*} \mathrm{CF} / \mathrm{K}$ measures cash flow sensitivity for unlisted firms in case of low concentration while the term $(1-\mathrm{L}) * \mathrm{CF} / \mathrm{K} * \mathrm{DHHI}$ reflects the extra effect when market concentration is high, i.e., when DHHI $=1$. The terms involving $\mathrm{L}$ can be interpreted similarly for listed companies. The results show that when one moves from low to high concentration, cash flow sensitivity drops significantly for unlisted firms. Or equivalently, when competition is intense, cash flow sensitivity is higher than in the case of weak competition. This pattern of increasing cash flow sensitivity with competitive pressure indicates financing constraints. For the listed firms the reverse happens. When one moves from low to high concentration, there is a significant increase in sensitivity. This finding therefore suggests that listed firms likely experience free cash flow problems when competitive intensity is low since cash flow sensitivity is significantly higher in these circumstances. Exactly similar findings are obtained in Model 3, where instead of market concentration, the strategic interaction dummy (DCSM) is used. In case of aggressive interaction or competition in strategic complements (DCSM = 1), unlisted firms become more financially constrained while in listed companies free cash flow problems are resolved. These results are completely in line with those concerning performance. Under intense competition or aggressive competitive interaction, the performance of unlisted companies declines while that of listed firms improves. In addition, compared with Model 1,

\footnotetext{
${ }^{32}$ As in the models of Table 3, we have deleted the separate variable whenever it was used to split up cash flow. However, when the models are augmented with the listing dummy, the coefficient of the latter becomes positive and significant; otherwise results remain totally intact. The inclusion of market concentration has no effect on our basic findings either while its coefficient remains insignificant.

${ }^{33}$ The dummy DHHI is used instead of HHI for the sake of interpreting the interaction terms with CF.
} 
this further split up of cash flow sensitivity into Models 2 and 3 has no impact on the control variables of the investment equation.

Finally, Table 7 includes interaction terms between the two measures of competition. Here, $(1-\mathrm{L}) * \mathrm{CF} / \mathrm{K}$ reflects cash flow sensitivity of the unlisted companies in case of competition in strategic substitutes (i.e., DCSM $=0)$. The term $(1-\mathrm{L}) * \mathrm{CF} / \mathrm{K} *(1-$ DHHI)*DCSM captures the extra effect of low concentration when competitive interaction is aggressive (i.e., when DCSM $=1)$. Similarly, the term $(1-\mathrm{L}) * \mathrm{CF} / \mathrm{K} * \mathrm{DHHI} * \mathrm{DCSM}$ reflects the extra impact of high concentration under competition in complements. The results show that increasing competitive pressure, from accommodating to aggressive competitive interaction, enhances cash flow sensitivity, and even more so when aggressive interaction is combined with low concentration. Hence, the pattern in investment-cash flow sensitivity suggests that unlisted firms increasingly suffer from financing constraints when strategic interaction is aggressive, and even more so when this is combined with intense competition. Just as in Table 6, the pattern reverses for listed firms. Interestingly, aggressive competition only has a significant disciplining effect when market concentration is low (i.e., when 1 DHHI = 1). Again, these findings are consistent with our earlier results for performance in Model 2 of Table 4.

$* * * * * * * * * * * * * * * * * * * * * * * * * * * * *$

INSERT TABLE 7 ABOUT HERE

$* * * * * * * * * * * * * * * * * * * * * * * * * * * * * *$

\section{CONCLUSIONS}

This paper studies the impact of competition on performance. Unlike the governance literature, which typically considers only listed companies, we extend our sample to large unlisted companies in order to include a broader range of access to external financing. This approach allows us to compare the impact of competition in companies with relatively less financing constraints but likely more free cash flow problems, with its impact in companies 
with likely significant financing constraints and less free cash flow problems. In line with the literature, we find that competition has a positive impact on performance for listed companies. Furthermore, estimates of investment-cash flow sensitivity indicate that without sufficient competitive pressure, free cash flow problems emerge. For unlisted companies we find exactly the reverse pattern. Performance declines under strong competitive pressure, while the cash flow sensitivity analysis reveals that under these circumstances companies suffer from increasing financing constraints.

Next to the classical inverse measures of competition, i.e., market concentration and the industry-specific Lerner index, we also use an empirical version of the competitive strategy measure that describes the type of strategic interactions predominant in a certain industry (i.e., competition in strategic complements or competition in strategic substitutes). We find that both aspects of competition not only influence firm performance directly, but they also tend to interact. Our evidence is consistent with the hypotheses that while competition in strategic complements is more likely to exacerbate financing constraints for firms with limited access to external financing, it plays a disciplining role to reduce free cash flow problems in unconstrained firms.

Our results also suggest several avenues for further research, as well as some policy implications. As a stock listing alleviates detrimental financial pressure, but in doing so can create free cash flow problems, an interesting avenue of research is the question of whether or not, and under what competitive conditions, other solutions to relax financing constraintslike business groups or private equity—could be more effective. Another interesting avenue concerns a more detailed investigation into the product market conditions under which firms opt for an IPO, and subsequently benefit from it. In terms of policy implications, our results show that, as listed firms are better able to withstand aggressive competition, in a world with globalizing and increasing competition, governments in countries with relatively few listed 
firms should be aware of the fact that limited use of the stock market contributes to the loss of competitive edge of their economies. Furthermore, our paper indicates that in designing policies to enhance competition, governments should be aware that it impacts quite differently on listed and unlisted firms of the industry, and in doing so provides some companies with a competitive advantage over others. Furthermore, our paper shows that also well established very large unlisted companies can suffer from financing constraints. This suggests that monetary tightening not only significantly affects smaller firms, but the investment behavior of the whole unlisted business sector.

\section{ACKNOWLEDGEMENTS}

We would like to thank Hans Degryse and Carolina Salva for insights and comments on earlier versions of the paper.

\section{REFERENCES}

Aghion P, Bloom N, Blundell R, Griffith R, Howitt P. 2005. Competition and innovation: An inverted U relationship. Quarterly Journal of Economics 120: 701-728.

Akdogu E, MacKay P. 2006. Investment and competition. Journal of Financial and Quantitative Analysis (forthcoming).

Allen F. 1993. Stock market and resource allocation. In Capital Markets and Financial Intermediation, Mayer C, Vives X (eds). Cambridge University Press: Cambridge, UK; 81-107.

Arellano M, Bond S. 1991. Some tests of specification for panel data: Monte Carlo evidence and an application to employment equations. Review of Economic Studies 58: 277-297.

Audretsch DB, Weigand J. 2005. Do knowledge conditions make a difference? Investment, Finance and Ownership in German industries. Research Policy 34: 595-613.

Barth E, Gulbrandsen T, Schone P. 2005. Family ownership and productivity: the role of owner-management. Journal of Corporate Finance 11: 107-127.

Bhagat S, Moyen N, Suh I. 2005. Investment and internal funds of distressed firms. Journal of Corporate Finance 11: 449-472.

Bianco M, Nicodano G. 2006. Pyramidal groups and debt. European Economic Review 50: 937-61.

Boyle GW, Guthrie G. 2003. Investment, uncertainty, and liquidity. Journal of Finance 58: 2143-2166.

Bozec R. 2005. Boards of directors, market discipline and firm performance. Journal of Business finance and accounting 32: 1921-1960.

Bulow J, Geanakoplos J, Klemperer P. 1985. Multimarket oligopoly: Strategic substitutes and complements. Journal of Political Economy 93: 488-511.

Campello M. 2003. Capital structure and product markets interactions: Evidence from the business cycles. Journal of Financial Economics 68: 353-378. 
Campello M. 2006. Debt financing: does it boost or hurt firm performance in product markets? Journal of Financial Economics 82: 135-172.

Caves RE. 2007. In Praise of the Old IO. International Journal of Industrial Organization 25: 1-12.

Chen S, Ho KW, Ik KH, Lee C. 2002. How does strategic competition affect firm values? A study of new product announcements. Financial Management 31: 67-84.

Chen S, Lin W, Shih YC. 2004. Strategic competition and the wealth effect of corporate capital investments. Unpublished working paper.

Chevalier JA. 1995a. Capital structure and product market competition: empirical evidence from the supermarket industry. American economic review 85: 415-435.

Chevalier JA. 1995b. Do LBO supermarkets charge more? An empirical analysis of the effects of the LBOs on supermarket pricing. Journal of finance 50: 1095-1112.

Claessens S, Tzioumis K. 2006. Ownership and financing structures of listed and large nonlisted corporations. Corporate Governance 14: 266-276.

Cleary S. 1999. The relationship between firm investment and financial status. Journal of Finance 54: 673-692.

Degryse H, de Jong A. 2006. Investment and internal finance: asymmetric information or managerial discretion? International Journal of Industrial Organization 24: 125-147.

Demirgüç-Kunt A, Maksimovic V. 1998. Law, finance, and firm growth. Journal of Finance 53: $2107-2137$.

Dewaelheyns N, Van Hulle C. 2006. Corporate failure prediction modelling: distorted by business groups' internal capital markets? Journal of Business Finance and Accounting 33: 909-31.

Dixit AK. 1989. Entry and exit decisions under uncertainty. Journal of Political Economy 97: 620-638.

Faure-Grimaud A, Gromb D. 2004. Public trading and private incentives. Review of financial Studies 17, 985-1014.

Fazzari SM, Hubbard RG, Petersen BC. 1988. Financing constraints and corporate investment. Brookings Papers on Economic Activity 1: 141-195.

Fudenberg D, Tirole J. 1984. The fat cat effect, the puppy dog ploy and the lean and hungry look. American Economic Review 74: 361-368.

Gedajlovic ER, Shapiro DM. 1998. Management and ownership effects: evidence from five countries. Strategic Management Journal 19(6): 533-553.

Ghosal V, Loungani P. 1996. Product market competition and the impact of price uncerntainty on investment: some evidence from US manufacturing industries. Journal of Industrial Economics 44: 217- 228.

Ghosal V, Loungani P. 2000. The differential impact of uncertainty on investment in small and large businesses. The Review of Economics and Statistics 82: 338-343.

Ghosal V. 2002. Potential foreign competition in U.S. manufacturing. International Journal of Industrial Organization 20: 1461-1489.

Giannetti M. 2003. Do better institutions mitigate agency problems? Evidence from corporate finance choices. Journal of Financial and Quantitative Analysis 38: 185-212.

Goddard J, Tavakoli M, Wilson J. 2005. Determinants of profitability in European manufacturing and services: Evidence from a dynamic panel data. Applied Financial Economics 15: 1269-1282.

Grenadier SR. 1996. The strategic exercise of options: development cascades and overbuilding in real estate markets. Journal of Finance 51: 1653-1679.

Hart OD. 1983. The Market Mechanism as an Incentive Scheme. Bell Journal of Economics 14: $366-82$.

Hennessy CA, Whited TM. 2005. Debt dynamics. Journal of Finance 60: 1129-1165. 
Hill C, Hansen G. 1991. A longitudinal study of the cause and consequences of changes in diversification in the U.S. pharmaceutical industry, 1977-1986. Strategic Management Journal 12(3): 187-199.

Holod D, Peek J. 2007. Asymmetric information and liquidity constraints: a new test. Journal of Banking and Finance 31: 2425-51.

Hou K, Robinson DT. 2006. Industry concentration and average stock returns. Journal of Finance 61: 1927-1956.

Hovakimian AG, Hovakimian G. 2007. Cash Flow Sensitivity of Investment. European Financial Management (Forthcomming).

Huyghebaert N, Van De Gucht L. 2004. Incumbent strategic behavior in financial markets and the exit of entrepreneurial start-ups. Strategic Management Journal 25(7): 669-688.

Jagannathan R, Srinivasan SB. 1999. Does product market competition reduce agency costs? North American Journal of Economics and Finance 10: 387-399.

Januszewski SI, Köke J, Winter JK. 2002. Product market competition, corporate governance and firm performance: an empirical analysis for Germany. Research in Economics 56: 299332.

Jensen MC. 1986. Agency cost of free cash flow, corporate finance, and takeovers. American Economic Review 76: 323-329.

Jensen MC. 1989. The eclipse of the public corporation. Harvard Business Review 67: 61-74.

Kaplan SN, Zingales L. 1997. Do investment cash flow sensitivities provide useful measures of financing constraints? The Quarterly Journal of Economics 20: 169-215.

Karuna C. 2007. Industry product market competition and managerial incentives. Journal of accounting and economics 43: 275-297.

Kedia S. 2006. Estimating product market competition: methodology and application. Journal of Banking and Finance 30: 875-894.

Kim J. 1999. The relaxation of financing constraints by the initial public offering of small manufacturing firms. Small Business Economics 12: 191-202.

Konings J, Rizov M, Vandenbussche H. 2003. Investment and financial constraints in transition economies: micro evidence from Poland, the Czech Republic, Bulgaria and Romania. Economic Letters 78: 253-258.

Kovenock D, Phillips G. 1997. Capital structure and product market behavior. Review of Financial Studies 10: 767-803.

La Porta R, Lopez-de-Silanes F, Shleifer A, Vishny R. 1999. Corporate ownership around the world. Journal of Finance 54: 471-517.

Levine R, Zervos S. 1998. Stock markets, banks, and economic growth. American Economic Review 88: 537-558.

Lyandres E. 2006. Capital structure and interaction among firms in output markets: theory and evidence. The Journal of Business 79: 2381-2421.

Mahérault L. 2000. The influence of going public on investment policy: an empirical study of French family-owned businesses. Family Business Review 13: 71-79

Maurer B. 1999. Innovation and investment under financial constraints and product market competition. International Journal of Industrial Organization 17: 455-476.

Mayer CP, Alexander I. 1991. Stock markets and corporate performance: A comparison of listed and unlisted companies. CEPR working paper, no. 571.

McConnell JJ, Servaes H. 1995. Equity ownership and the two faces of debt. Journal of Financial Economics 39: 131-157.

McDonald R, Siegel D. 1986. The value of waiting to invest. Quarterly Journal of Economics 101: 707-728.

Myers SC. 2000. Outside equity. The Journal of Finance 55: 1005-1037. 
Nalebuff BJ, Stiglitz JE. 1983. Information, competition, and markets. American Economic Review: Papers and Proceedings 73: 278-283.

Nickell S. 1996. Competition and corporate performance. Journal of political economy 104: 704-746.

Nickell S, Nicolitsas D, Dryden N. 1997. What makes firms perform well? European Economic Review 41: 783-796.

Nickell S, Nicolitsas D. 1999. How does financial pressure affect firms? European Economic Review 43: 1435-1456.

Pagano M, Panetta F, Zingales L. 1998. Why do companies go public? An Empirical Analysis. Journal of Finance 53: 27-64.

Palia D, Lichtenberg F. 1999. Managerial ownership and firm performance: A reexamination using productivity measurement. Journal of Corporate Finance 5: 323-339.

Pawlina G, Renneboog L. 2005. Is investment-cash flow sensitivity caused by the agency costs or asymmetric information? Evidence from the UK. European Financial Management 11: 483-513.

Phillips GM. 1995. Increased debt and industry product markets: an empirical analysis. Journal of Financial Economics 37: 189-238.

Pindyck RS. 1988. Irreversible investment, capacity choice, and the value of the firm. American Economic Review 78: 969-985.

Povel P, Raith M. 2004. Financial constraints and product market competition: ex ante vs. ex post incentives. International Journal of Industrial Organization 22: 917- 949.

Rajan RG. 1992. Insiders and outsiders: the choice between informed and arm's-length debt. Journal of Finance 47: 1367-1400.

Rajan RG, Zingales L. 1998. Financial dependence and growth. American Economic Review 88: 559-587.

Robinson KC, McDougall PP. 1998. The impact of alternative operationalizations of industry structural elements on measures of performance for entrepreneurial manufacturing ventures. Strategic Management Journal 19(11): 1079-1100.

Rogers M. 2004. Competition, agency and productivity. Int. Journal of the Economics of Business 17: 349-367.

Schoar A. 2002. Effects of corporate diversification on productivity. Journal of Finance 57: 2379-2403.

Slade M. 2004. Competing models of firm profitability. International Journal of Industrial Organization 22: 289-308.

Spanos Y, Zaralis G, Lioukas S. 2004. Strategy and industry effects on profitability: evidence from Greece. Strategic Management Journal 25(2): 139-165.

Sundaram AK, John TA, John K. 1996. An empirical analysis of strategic competition and firm values The case of R\&D competition. Journal of financial economics 40: 459-486.

Thomsen S, Pedersen T. 2000. Ownership structure and economic performance in the largest European companies. Strategic Management Journal 21(6): 689-705.

Williams JT. 1993. Equilibrium and options on real assets. Review of Financial Studies 6: 825-850.

Zingales L. 1998. Survival of the fittest or the fattest? Exit and financing in the trucking industry. Journal of Finance 53: 905-938. 


\section{APPENDIX}

Variable definitions

Performance variables

TFP

Firm-level total factor productivity (TFP) is measured as the residual of the industryspecific log-linear Cobb-Douglas production function.

ROA (Earnings before interest and taxes)/(Total assets)

Control variables

SIZE Ln(Total assets)

FINLEV (Interest bearing debt)/(Total assets)

GROWTH Salesgrowth

\section{Product market competition variables}

Herfindahl Hirschman Index for a certain year measured as the sum of squared market

$\mathrm{HHI}$ shares over all companies in an industry (based on 3 digit Nace Codes of all consolidating European companies from in the Amadeus database), using turnover. Industry-specific (based on 3 digit Nace Codes of all consolidating European companies

Lerner from the Amadeus database) Lerner index averaging the firm's price-cost-margins (net profit divided by turnover) for a particular year.

Coefficient of correlation in a certain year between each firm's marginal profit (the

CSM change in profits divided by the change in turnover) and the change in competitor output (based on 3 digit Nace Codes of all consolidating European companies from the Amadeus database) using turnover.

\section{Stock market listing variable}

$\mathrm{L}$

Dummy variable with value 1 if a firm was listed in a certain year and 0 otherwise.

\section{Investment model variables}

$\mathrm{I} / \mathrm{K}$

$\Delta \mathrm{S} / \mathrm{K}$

$\mathrm{CF} / \mathrm{K}$

$\triangle \mathrm{WC} / \mathrm{K}$ $\triangle$ FINDEBT/K
(Annual change in fixed tangible assets + depreciation)/(Fixed tangible assets)

(Annual change in sales)/(Fixed tangible assets)

(Earnings before interests, taxes and depreciation - interests paid - taxes)/(Fixed tangible assets)

(Annual change in net working capital)/(Fixed tangible assets)

(Annual change in interest bearing debt)/(Fixed tangible assets) 
Table 1: Sample Composition

Panel A: Panel data structure

\begin{tabular}{lrrr}
\hline Year & All Firms & Unlisted & Listed \\
\hline 1993 & 161 & 123 & 38 \\
1994 & 155 & 118 & 37 \\
1995 & 128 & 98 & 30 \\
1996 & 110 & 80 & 30 \\
1997 & 156 & 112 & 44 \\
1998 & 172 & 120 & 52 \\
1999 & 207 & 144 & 63 \\
2000 & 220 & 150 & 70 \\
2001 & 253 & 183 & 70 \\
2002 & 276 & 203 & 73 \\
2003 & 230 & 164 & 66 \\
2004 & 238 & 170 & 68 \\
2005 & 212 & 147 & 65 \\
& & & \\
All & 2518 & 1812 & 706 \\
\hline
\end{tabular}

Panel B: Industry distribution

\begin{tabular}{lrrr}
\hline Industry & Number of firms & Unlisted & Listed \\
\hline Food \& Agriculture & 44 & 34 & 10 \\
Manufacturing & 137 & 96 & 41 \\
Construction & 20 & 17 & 3 \\
Distribution & 82 & 64 & 18 \\
Transportation & 29 & 27 & 2 \\
Services & 124 & 98 & 26 \\
Total firms & & & \\
\hline
\end{tabular}


Tabel 2: Descriptive statistics.

\begin{tabular}{|c|c|c|c|c|c|c|}
\hline \multicolumn{7}{|c|}{ Panel A: Summary statistics } \\
\hline & & $\begin{array}{c}\text { Full } \\
\text { Sample }\end{array}$ & Unlisted & Listed & Test & p-values \\
\hline \multirow{2}{*}{ TFP } & Mean & 0.0074 & -0.0087 & 0.0808 & $31.99 * * *$ & 0.00 \\
\hline & Median & 0.0068 & -0.0054 & 0.0636 & $5.23 * * *$ & 0.00 \\
\hline \multirow{2}{*}{ ROA } & Mean & 0.0564 & 0.0554 & 0.0610 & $4.18^{* *}$ & 0.04 \\
\hline & Median & 0.0505 & 0.0494 & 0.0545 & $2.91 * * *$ & 0.00 \\
\hline \multirow{2}{*}{ SIZE } & Mean & 11.59 & 11.47 & 12.15 & $169.21 * * *$ & 0.00 \\
\hline & Median & 11.38 & 11.28 & 12.11 & $11.74 * * *$ & 0.00 \\
\hline \multirow{2}{*}{ FINLEV } & Mean & 0.2471 & 0.2505 & 0.2317 & $5.62 * *$ & 0.02 \\
\hline & Median & 0.2345 & 0.2408 & 0.2169 & $2.41 * *$ & 0.02 \\
\hline \multirow{2}{*}{ GROWTH } & Mean & 0.0561 & 0.0479 & 0.0907 & $16.92 * * *$ & 0.00 \\
\hline & Median & 0.0440 & 0.0404 & 0.0582 & $3.56 * * *$ & 0.00 \\
\hline
\end{tabular}

\begin{tabular}{|c|c|c|c|c|c|}
\hline \multicolumn{6}{|c|}{ Panel B: Performance measures and market concentration } \\
\hline \multicolumn{6}{|c|}{ Unlisted Firms } \\
\hline & & $\mathrm{DHHI}=0$ & $\mathrm{DHHI}=1$ & Test & p-values \\
\hline \multirow{2}{*}{ TFP } & Mean & -0.0187 & 0.0039 & $2.86 *$ & 0.09 \\
\hline & Median & -0.0063 & -0.0031 & 0.75 & 0.45 \\
\hline \multirow{2}{*}{ ROA } & Mean & 0.0590 & 0.0507 & $12.83 * * *$ & 0.00 \\
\hline & Median & 0.0502 & 0.0473 & $2.76^{* * *}$ & 0.01 \\
\hline \multicolumn{6}{|c|}{ Listed Firms } \\
\hline & & $\mathrm{DHHI}=0$ & DHHI = 1 & Test & $\mathrm{p}$-values \\
\hline \multirow{2}{*}{ TFP } & Mean & 0.0907 & 0.0767 & 0.18 & 0.66 \\
\hline & Median & 0.0912 & 0.0466 & $1.62 *$ & 0.10 \\
\hline \multirow{2}{*}{ ROA } & Mean & 0.0677 & 0.0583 & 2.53 & 0.11 \\
\hline & Median & 0.0599 & 0.0540 & $1.64^{*}$ & 0.10 \\
\hline
\end{tabular}

\begin{tabular}{|c|c|c|c|c|c|}
\hline \multicolumn{6}{|c|}{ Panel C: Performance measures and competitive strategy measure } \\
\hline & & $\mathrm{DCSM}-0$ & $\mathrm{DCSM}=1$ & Test & n.yolues \\
\hline \multirow{2}{*}{ TFP } & Mean & -0.0006 & -0.0170 & 1.49 & 0.22 \\
\hline & Median & -0.0037 & -0.0064 & 0.41 & 0.67 \\
\hline \multirow{2}{*}{ ROA } & Mean & 0.0567 & 0.0540 & 1.41 & 0.23 \\
\hline & Median & 0.0508 & 0.0487 & 1.17 & 0.24 \\
\hline \multicolumn{6}{|c|}{ Listed Firms } \\
\hline & & $\mathrm{DCSM}=0$ & $\mathrm{DCSM}=1$ & Test & p-values \\
\hline \multirow{2}{*}{ TFP } & Mean & 0.0724 & 0.0907 & 0.38 & 0.53 \\
\hline & Median & 0.0594 & 0.0656 & 0.31 & 0.75 \\
\hline \multirow{2}{*}{ ROA } & Mean & 0.0590 & 0.0635 & 0.70 & 0.40 \\
\hline & Median & 0.0539 & 0.0573 & 0.80 & 0.42 \\
\hline
\end{tabular}




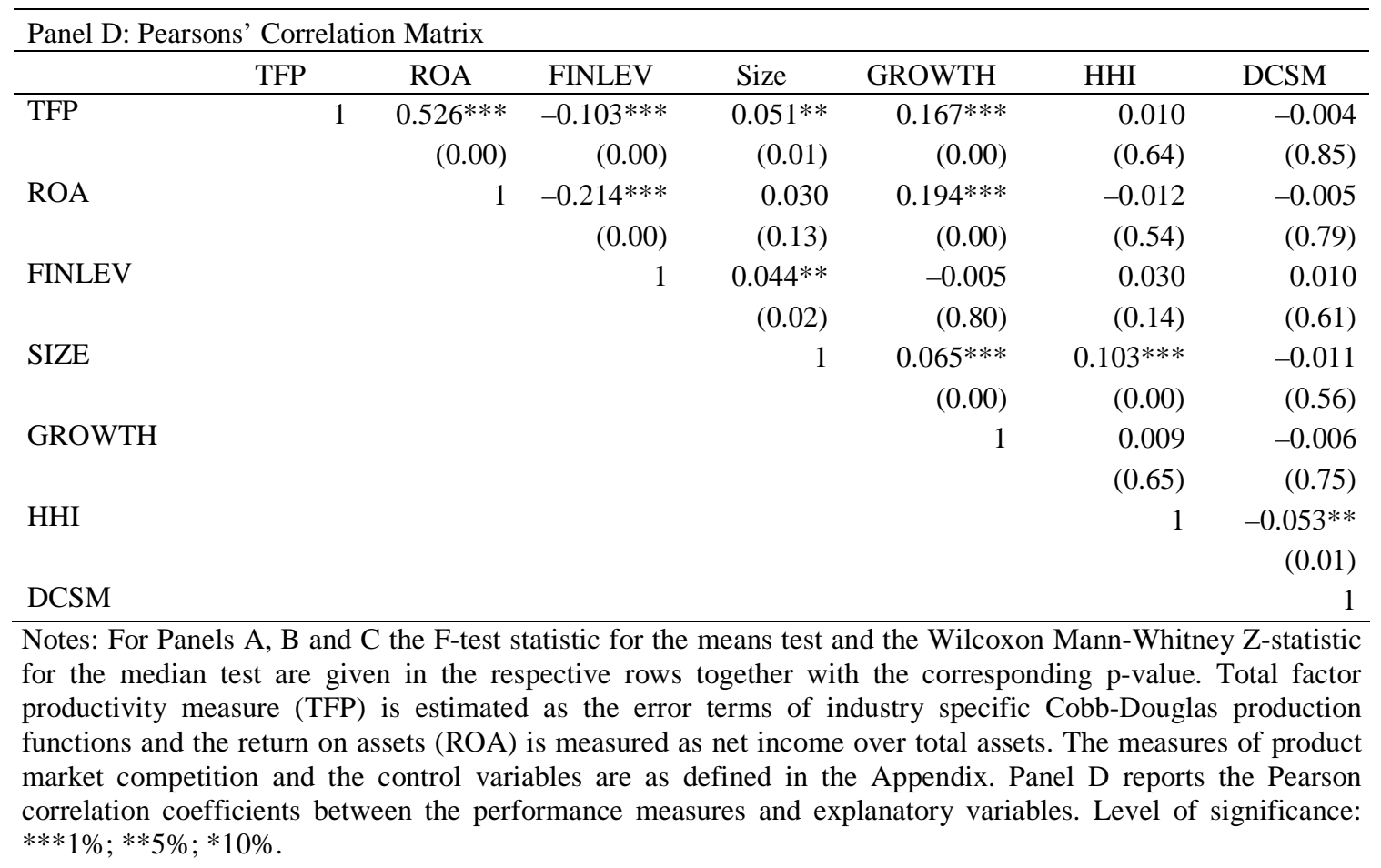


Table 3: Performance models

\begin{tabular}{|c|c|c|c|c|}
\hline \multirow{2}{*}{$\begin{array}{l}\text { Explanatory } \\
\text { variables }\end{array}$} & \multicolumn{2}{|c|}{ Model 1} & \multicolumn{2}{|c|}{ Model 2} \\
\hline & TFP & ROA & TFP & ROA \\
\hline Performance(-1) & $\begin{array}{c}0.1144 * * * \\
(4.97)\end{array}$ & $\begin{array}{c}0.3765 * * * \\
(11.71)\end{array}$ & $\begin{array}{c}0.0621 * * * \\
(2.90)\end{array}$ & $\begin{array}{c}0.3631 * * * \\
(11.22)\end{array}$ \\
\hline SIZE & $\begin{array}{c}-0.1988 * * * \\
(-6.97)\end{array}$ & $\begin{array}{c}-0.0497 * * * \\
(-5.07)\end{array}$ & $\begin{array}{c}-0.2236 * * * \\
(-8.46)\end{array}$ & $\begin{array}{c}-0.0499 * * * \\
(-5.94)\end{array}$ \\
\hline FINLEV & $\begin{array}{c}-0.2402 * * * \\
(-2.74)\end{array}$ & $\begin{array}{c}-0.0564 * \\
(-1.82)\end{array}$ & $\begin{array}{c}-0.2242 * * * \\
(-2.74)\end{array}$ & $\begin{array}{c}-0.0682 * * \\
(-2.29)\end{array}$ \\
\hline GROWTH & $\begin{array}{c}0.2344 * * * \\
(7.51)\end{array}$ & $\begin{array}{c}0.0252 * * * \\
(5.70)\end{array}$ & $\begin{array}{c}0.1795 * * * \\
(6.82)\end{array}$ & $\begin{array}{c}0.0246 * * * \\
(5.46)\end{array}$ \\
\hline HHI & $\begin{array}{c}0.1198 * * * \\
(2.73)\end{array}$ & $\begin{array}{c}0.0301 * \\
(1.61)\end{array}$ & $\begin{array}{c}0.1454 * * * \\
(3.34)\end{array}$ & $\begin{array}{c}0.0305^{*} \\
(1.69)\end{array}$ \\
\hline DCSM & 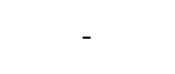 & - & $\begin{array}{c}-0.0348^{*} \\
(-1.81)\end{array}$ & $\begin{array}{c}-0.0040^{*} \\
(-1.65)\end{array}$ \\
\hline $\mathrm{L}$ & $\begin{array}{c}0.5666^{*} \\
(1.66)\end{array}$ & $\begin{array}{c}0.0834 * * \\
(1.99)\end{array}$ & $\begin{array}{c}0.6032 * \\
(1.68)\end{array}$ & $\begin{array}{c}0.0782 * * \\
(2.12)\end{array}$ \\
\hline Sargan Test & 0.627 & 0.653 & 0.666 & 0.662 \\
\hline $\mathrm{m} 1$ & $* * *$ & $* * *$ & $* * *$ & $* * *$ \\
\hline $\mathrm{m} 2$ & n.s. & n.s. & n.s. & n.s. \\
\hline
\end{tabular}

Notes: The dependent variable is either the total factor productivity measure (TFP) estimated as the error terms of industry specific Cobb-Douglas production functions or the return on assets (ROA). The measures of product market competition and the control variables are as defined in the Appendix. Models are tested with GMM, estimated in first differences using the Arellano and Bond (1991) method (White's heteroskedasticity consistent t-statistics in parentheses). The validity of using lagged values from $t-2$ and before of endogenous regressors as instruments was evaluated with the Sargan test of over-identifying restrictions and direct tests of serial correlation in the residuals $\mathrm{m} 1$ and $\mathrm{m} 2$. The Sargan test is $\chi^{2}$ distributed; its $p$-values are reported in the Table. Levels of significance: $* * * 1 \% ; * * 5 \% ; * 10 \%$; n.s. indicates non significance. 
Table 4: Interaction of competition measures in performance models

\begin{tabular}{|c|c|c|c|c|c|}
\hline \multirow{2}{*}{$\begin{array}{l}\text { Explanatory } \\
\text { variables }\end{array}$} & \multicolumn{2}{|c|}{ Model 1} & & \multicolumn{2}{|c|}{ Model 2} \\
\hline & TFP & ROA & & TFP & ROA \\
\hline Performance(-1) & $\begin{array}{c}0.1198 * * * \\
(5.92)\end{array}$ & $\begin{array}{c}0.3943 * * * \\
(12.33)\end{array}$ & Performance(-1) & $\begin{array}{c}0.1017 * * * \\
(5.18)\end{array}$ & $\begin{array}{c}0.3388 * * * \\
(9.69)\end{array}$ \\
\hline SIZE & $\begin{array}{c}-0.1485 * * * \\
(-5.55)\end{array}$ & $\begin{array}{c}-0.0438 * * * \\
(-5.03)\end{array}$ & SIZE & $\begin{array}{c}-0.1252 * * * \\
(-4.86)\end{array}$ & $\begin{array}{c}-0.0356 * * * \\
(-4.32)\end{array}$ \\
\hline FINLEV & $\begin{array}{c}-0.2227 * * * \\
(-2.67)\end{array}$ & $\begin{array}{c}-0.0921 * * * \\
(-2.75)\end{array}$ & FINLEV & $\begin{array}{c}-0.2165 * * * \\
(-2.88)\end{array}$ & $\begin{array}{c}-0.0671 * * \\
(-2.18)\end{array}$ \\
\hline GROWTH & $\begin{array}{c}0.2394 * * * \\
(8.05)\end{array}$ & $\begin{array}{c}0.0258 * * * \\
(5.64)\end{array}$ & GROWTH & $\begin{array}{c}0.2183 * * * \\
(7.56)\end{array}$ & $\begin{array}{c}0.0235 * * * \\
(5.44)\end{array}$ \\
\hline$(1-\mathrm{L}) * \mathrm{HHI}$ & $\begin{array}{l}0.3000 * * * \\
(3.08)\end{array}$ & $\begin{array}{l}0.0761 * * * \\
(3.94)\end{array}$ & $\begin{array}{l}(1-\mathrm{L}) *(1-\mathrm{DHHI}) \\
* \mathrm{DCSM}\end{array}$ & $\begin{array}{c}-0.1085 * * * \\
(-3.68)\end{array}$ & $\begin{array}{c}-0.0114 * * \\
(-2.40)\end{array}$ \\
\hline L*HHI & $\begin{array}{c}-0.7865^{* *} \\
(-2.04)\end{array}$ & $\begin{array}{c}-0.1337 * * \\
(-2.11)\end{array}$ & $\begin{array}{l}(1-\mathrm{L}) * \mathrm{DHHI} * \\
\text { DCSM }\end{array}$ & $\begin{array}{c}0.0274 \\
(1.28)\end{array}$ & $\begin{array}{c}0.0016 \\
(0.26)\end{array}$ \\
\hline$(1-\mathrm{L}) * \mathrm{DCSM}$ & $\begin{array}{c}-0.0482 * * * \\
(-2.82)\end{array}$ & $\begin{array}{c}-0.0081 * * * \\
(-2.60)\end{array}$ & $\begin{array}{l}\mathrm{L}^{*}(1-\mathrm{DHHI}) * \\
\text { DCSM }\end{array}$ & $\begin{array}{c}0.1474 * * \\
(2.05)\end{array}$ & $\begin{array}{c}0.0465 * * \\
(2.27)\end{array}$ \\
\hline L*DCSM & $\begin{array}{c}0.1640 * * * \\
(2.66)\end{array}$ & $\begin{array}{c}0.0171 * \\
(1.68)\end{array}$ & $\begin{array}{l}\mathrm{L}^{*} \mathrm{DHHI} * \\
\text { DCSM }\end{array}$ & $\begin{array}{c}-0.0093 \\
(-0.10) \\
\end{array}$ & $\begin{array}{c}-0.0037 \\
(-0.35) \\
\end{array}$ \\
\hline Sargan Test & 0.389 & 0.578 & & 0.496 & 0.823 \\
\hline $\mathrm{m} 1$ & $* * *$ & $* * *$ & & $* * *$ & $* * *$ \\
\hline $\mathrm{m} 2$ & n.s. & n.s. & & n.s. & n.s. \\
\hline
\end{tabular}

Notes: The dependent variable is either the total factor productivity measure (TFP) estimated as the error terms of industry specific Cobb-Douglas production functions or the return on assets (ROA). The measures of product market competition and the control variables are as defined in the Appendix. Models are tested with GMM, estimated in first differences using the Arellano and Bond (1991) method (White's heteroskedasticity consistent t-statistics in parentheses). The validity of using lagged values from t-2 and before of endogenous regressors as instruments was evaluated with the Sargan test of overidentifying restrictions and direct tests of serial correlation in the residuals $\mathrm{m} 1$ and $\mathrm{m} 2$. The Sargan test is $\chi^{2}$ distributed; its $p$-values are reported in the Table. Levels of significance: ***1\%; **5\%; *10\%; n.s. indicates non significance. 
Table 5: Alternative measures of competition in performance models

\begin{tabular}{|c|c|c|c|c|c|}
\hline \multirow{2}{*}{$\begin{array}{l}\text { Explanatory } \\
\text { variables }\end{array}$} & \multicolumn{2}{|c|}{ Model 1} & & \multicolumn{2}{|c|}{ Model 2} \\
\hline & TFP & ROA & & TFP & ROA \\
\hline Performance(-1) & $\begin{array}{c}0.1062 * * * \\
(5.31)\end{array}$ & $\begin{array}{l}0.3221 * * * \\
(7.84)\end{array}$ & Performance(-1) & $\begin{array}{c}0.1293 * * * \\
(6.41)\end{array}$ & $\begin{array}{l}0.2557 * * * \\
(6.57)\end{array}$ \\
\hline SIZE & $\begin{array}{c}-0.1427 * * * \\
(-5.26)\end{array}$ & $\begin{array}{c}-0.0345^{* * * *} \\
(-4.19)\end{array}$ & SIZE & $\begin{array}{c}-0.1635^{* * * *} \\
(-5.81)\end{array}$ & $\begin{array}{c}-0.0409 * * * \\
(-5.92)\end{array}$ \\
\hline FINLEV & $\begin{array}{c}-0.2650 * * * \\
(-3.07)\end{array}$ & $\begin{array}{c}-0.1558 * * * \\
(-4.38)\end{array}$ & FINLEV & $\begin{array}{c}-0.2148 * * * \\
(-2.58)\end{array}$ & $\begin{array}{c}-0.1442 * * * \\
(-3.84)\end{array}$ \\
\hline GROWTH & $\begin{array}{c}0.2364 * * * \\
(7.42)\end{array}$ & $\begin{array}{l}0.0222 * * * \\
\quad(5.16)\end{array}$ & GROWTH & $\begin{array}{l}0.2251 * * * \\
(7.04)\end{array}$ & $\begin{array}{l}0.0192 * * * \\
\quad(4.68)\end{array}$ \\
\hline$(1-\mathrm{L}) * \mathrm{LERN}$ & $\begin{array}{c}1.4127 * * * \\
(2.73)\end{array}$ & $\begin{array}{c}0.0141 * * * \\
(2.68)\end{array}$ & $\begin{array}{l}(1-\mathrm{L}) *(1-\mathrm{DLERN}) \\
* \mathrm{DCSM}\end{array}$ & $\begin{array}{c}-0.0835 * * \\
(-2.50)\end{array}$ & $\begin{array}{c}-0.0108 * * \\
(-2.33)\end{array}$ \\
\hline L*LERN & $\begin{array}{c}-3.9416 * * * \\
(-2.97)\end{array}$ & $\begin{array}{c}-0.0655 * * * \\
(-2.77)\end{array}$ & $\begin{array}{l}(1-\mathrm{L}) * \text { DLERN* } \\
\text { DCSM }\end{array}$ & $\begin{array}{c}0.0078 \\
(0.25)\end{array}$ & $\begin{array}{c}0.0091 \\
(1.65)\end{array}$ \\
\hline$(1-\mathrm{L}) * \mathrm{DCSM}$ & $\begin{array}{c}-0.0596^{* * * *} \\
(-3.15)\end{array}$ & $\begin{array}{c}-0.0075 * * \\
(-2.41)\end{array}$ & $\begin{array}{l}\text { L*(1-DLERN }) * \\
\text { DCSM }\end{array}$ & $\begin{array}{c}0.2464 * * * \\
(2.79)\end{array}$ & $\begin{array}{l}0.0204 * * \\
(1.93)\end{array}$ \\
\hline L*DCSM & $\begin{array}{l}0.2133 * * * \\
(3.09)\end{array}$ & $\begin{array}{c}0.0198^{*} \\
(1.93)\end{array}$ & $\begin{array}{l}\text { L*DLERN* } \\
\text { DCSM }\end{array}$ & $\begin{array}{c}0.0559 \\
(0.62)\end{array}$ & $\begin{array}{c}-0.0194 \\
(-1.11)\end{array}$ \\
\hline Sargan Test & 0.733 & 0.672 & & 0.878 & 0.446 \\
\hline $\mathrm{m} 1$ & $* * *$ & $* * *$ & & $* * *$ & $* * *$ \\
\hline $\mathrm{m} 2$ & n.s. & n.s. & & n.s. & n.s. \\
\hline
\end{tabular}

Notes: The dependent variable is either the total factor productivity measure (TFP) estimated as the error terms of industry specific Cobb-Douglas production functions or the return on assets (ROA). The measures of product market competition and the control variables are as defined in the Appendix. Models are tested with GMM, estimated in first differences using the Arellano and Bond (1991) method (White's heteroskedasticity consistent t-statistics in parentheses). The validity of using lagged values from $\mathrm{t}-2$ and before of endogenous regressors as instruments was evaluated with the Sargan test of overidentifying restrictions and direct tests of serial correlation in the residuals $\mathrm{m} 1$ and $\mathrm{m} 2$. The Sargan test is $\chi^{2}$ distributed; its $p$-values are reported in the Table. Levels of significance: ***1\%; **5\%; *10\%; n.s. indicates non significance. 
Table 6: Basic investment models

\begin{tabular}{|c|c|c|c|}
\hline Explanatory variables & Model 1 & Model 2 & Model 3 \\
\hline$\Delta \mathrm{S} / \mathrm{K}$ & $\begin{array}{c}0.1376 * * * \\
(147.49)\end{array}$ & $\begin{array}{c}0.1363 * * * \\
(94.33)\end{array}$ & $\begin{array}{c}0.1409 * * * \\
(132.74)\end{array}$ \\
\hline$(1-\mathrm{L}) * \mathrm{CF} / \mathrm{K}$ & $\begin{array}{c}0.5494 * * * \\
(9.06)\end{array}$ & $\begin{array}{c}0.6344 * * * \\
(6.76)\end{array}$ & $\begin{array}{c}0.3336 * * * \\
(4.83)\end{array}$ \\
\hline$(1-\mathrm{L}) * \mathrm{CF} / \mathrm{K} * \mathrm{DHHI}$ & 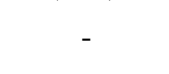 & $\begin{array}{c}-0.4993 * * * \\
(-5.73)\end{array}$ & 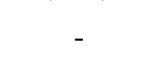 \\
\hline$(1-\mathrm{L}) * \mathrm{CF} / \mathrm{K}^{*} \mathrm{DCSM}$ & 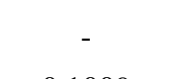 & 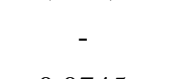 & $\begin{array}{c}0.5224 * * * \\
(10.11)\end{array}$ \\
\hline $\mathrm{L} * \mathrm{CF} / \mathrm{K}$ & $\begin{array}{c}0.1009 \\
(1.10)\end{array}$ & $\begin{array}{c}0.0745 \\
(1.18)\end{array}$ & $\begin{array}{c}0.2659 * * * \\
(2.78)\end{array}$ \\
\hline $\mathrm{L} * \mathrm{CF} / \mathrm{K} * \mathrm{DHHI}$ & 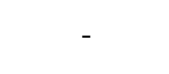 & $\begin{array}{c}0.1885^{*} \\
(1.87)\end{array}$ & 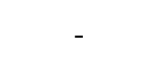 \\
\hline $\mathrm{L}^{*} \mathrm{CF} / \mathrm{K} * \mathrm{DCSM}$ & $=0$ & 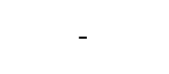 & $\begin{array}{c}-0.2903 * * \\
(-2.49)\end{array}$ \\
\hline$\Delta \mathrm{WC} / \mathrm{K}$ & $\begin{array}{c}-0.5515^{* * *} * \\
(-3.00)\end{array}$ & $\begin{array}{c}-0.6212 * * * \\
(-3.27)\end{array}$ & $\begin{array}{c}-0.3865 * * \\
(-2.22)\end{array}$ \\
\hline$\Delta$ FINDEBT/K & $\begin{array}{l}0.1124 * * * \\
\quad(7.76)\end{array}$ & $\begin{array}{c}0.0871 * * * \\
(5.11)\end{array}$ & $\begin{array}{c}0.1131 * * * \\
(6.24)\end{array}$ \\
\hline SIZE & $\begin{array}{c}0.2162 * * * \\
(6.64)\end{array}$ & $\begin{array}{c}0.3182 * * * \\
(9.88)\end{array}$ & $\begin{array}{c}0.2817 * * * \\
(7.41)\end{array}$ \\
\hline HHI & $\begin{array}{c}-0.0107 \\
(-0.15) \\
\end{array}$ & - & - \\
\hline Sargan Test & 0.209 & 0.513 & 0.143 \\
\hline $\mathrm{m} 1$ & $* * *$ & $* * *$ & $* * *$ \\
\hline $\mathrm{m} 2$ & n.s. & n.s. & n.s. \\
\hline
\end{tabular}

Notes: The dependent variable in all models is the investment ratio $(\mathrm{I} / \mathrm{K})$, explanatory variables are defined in the appendix. Models are tested with GMM, estimated in first differences using the Arellano and Bond (1991) method (White's heteroskedasticity consistent t-statistics in parentheses). The validity of using lagged values from t-2 and before of endogenous regressors as instruments was evaluated with the Sargan test of over-identifying restrictions and direct tests of serial correlation in the residuals $\mathrm{m} 1$ and $\mathrm{m} 2$. The Sargan test is $\chi^{2}$ distributed; its $p$-values are reported in the Table. Levels of significance: $* * * 1 \% ; * * 5 \% ; * 10 \%$; n.s. indicates non significance. 
Table 7: Interactions of competition measures in investment models

\begin{tabular}{lc}
\hline Explanatory variables & \\
\hline$\Delta \mathrm{S} / \mathrm{K}$ & $(140.00)$ \\
& $0.3110^{* * *}$ \\
$(1-\mathrm{L})^{*} \mathrm{CF} / \mathrm{K}$ & $(4.74)$ \\
$(1-\mathrm{L})^{*} \mathrm{CF} / \mathrm{K}^{*}$ & $0.7875^{* * *}$ \\
$(1-\mathrm{DHHI})^{*} \mathrm{DCSM}$ & $(6.07)$ \\
$(1-\mathrm{L})^{*} \mathrm{CF} / \mathrm{K}^{*}$ & $0.3187 * * *$ \\
$\mathrm{DHHI}{ }^{*} \mathrm{DCSM}$ & $(3.55)$ \\
$\mathrm{L}^{*} \mathrm{CF} / \mathrm{K}$ & $0.2152^{* *}$ \\
$\mathrm{~L} * \mathrm{CF} / \mathrm{K} *$ & $(2.16)$ \\
$(1-\mathrm{DHHI})^{*} \mathrm{DCSM}$ & $-0.3381^{*}$ \\
$\mathrm{~L} * \mathrm{CF} / \mathrm{K} *$ & $(-1.72)$ \\
$\mathrm{DHHI}{ }^{*} \mathrm{DCSM}$ & -0.1768 \\
$\Delta \mathrm{WC} / \mathrm{K}$ & $(-0.92)$ \\
& $-0.3251^{*}$ \\
$\Delta \mathrm{FINDEBT} / \mathrm{K}$ & $(-1.74)$ \\
& $0.1333^{* * *}$ \\
$\mathrm{SIZE}$ & $(4.61)$ \\
& $0.2790 * * *$ \\
Sargan Test & $(3.38)$ \\
$\mathrm{m} 1$ & 0.411 \\
$\mathrm{~m} 2$ & $* * *$ \\
\hline
\end{tabular}

Notes: The dependent variable in all models is the investment ratio (I/K), explanatory variables are defined in the appendix. Models are tested with GMM, estimated in first differences using the Arellano and Bond (1991) method (White's heteroskedasticity consistent t-statistics in parentheses). The validity of using lagged values from $\mathrm{t}-2$ and before of endogenous regressors as instruments was evaluated with the Sargan test of over-identifying restrictions and direct tests of serial correlation in the residuals $\mathrm{m} 1$ and $\mathrm{m} 2$. The Sargan test is $\chi^{2}$ distributed; its $p$-values are reported in the Table. Levels of significance: $* * * 1 \% ; * * 5 \% ; * 10 \%$; n.s. indicates non significance. 